\title{
Benthic diatom communities and their relationship to water chemistry in wetlands of central Italy
}

\author{
V. Della Bella*, C. Puccinelli, S. Marcheggiani, L. Mancini
}

Department of Environment and Primary Prevention, National Institute of Health, Viale Regina Elena 299, 00161 Rome, Italy.

\begin{abstract}
Diatoms are good environmental indicators and are often the main component of phytobenthos, one of the key groups of organisms recommended by the Water Framework Directive (W.F.D.) for the assessment of ecological status of surface waters. Although diatoms are regularly used as indicators in rivers and in lakes, less is known about the benthic diatom communities in wetland systems, especially in Italy. The main aim of the project was to provide a contribution to the knowledge on distribution, composition and structure of benthic diatom communities in wetland systems in Italy. In 2005, we investigated the benthic diatom communities and their relationships to water variables of nine ponds and wetlands along the Tyrrhenian coast near Rome. Furthermore, a first application of seven European diatom-based indices on this type of water body was undertaken. A total of 225 species and varieties belonging to 54 genera were identified. The Canonical Correspondence Analysis indicated that certain species were closely associated with each wetland type and their distribution mainly depended on nutrient and chloride contents: pollution tolerant species (i. e. Luticola goeppertiana, Mayamaea atomus, Navicula subminuscula) in the wetlands connected to river mouths, halophilous species and also marine littoral species (i. e. Nitzschia elegantula, Amphora coffeaeformis, Achnanthes brevipes var. intermedia, Epithemia adnata var. porcellus) in the coastal brackish ponds and wetlands, and less eutrophic species (i. e. Achnanthidium minutissimum, A. biasolettianum) in the lowland freshwater wetland. In general, the indices classified most of the studied water bodies as bad, poor and moderate status; few sites were classified into a good class, even for at least in one sampling occasion. Eutrophication and Pollution Index (EPI-D), Trophic Diatom Index (TDI), Taxa Pollution Tolerant (\%PT), Pollution Sensitivity Index (IPS) and Generic Diatom Index (IDG) were significantly correlated to nutrient contents in the studied wetlands. Our preliminary data set illustrated the potential of the use of these benthic algae as bioindicators in wetlands.
\end{abstract}

Keywords: Bacillariophyceae, algae, biomonitoring, Water Framework Directive

\section{Introduction}

Phytobenthos is one of the key groups of organisms recommended by the European Union Water Framework Directive 2000/60 (W.F.D.) for the assessment of ecological status of surface waters (CEC 2000). Diatoms are often the main component of phytobenthos and phytoplankton in the surface water bodies, representing an important element in aquatic ecosystems and one of the most important groups of algae for monitoring activities (Kelly et al. 1998, Mancini 2005, King et al. 2006). Their biological and ecological characteristics make them good indicators of water quality, and their use is widespread and well developed for evaluating the quality of flowing water (for a review see Prygiel et al. 1999) and standing waters, particularly lakes (Kitner \& Poulî́cková 2003, Blanco et al. 2004, DeNicola \& et al. 2004, Denys 2004, King et al. 2006). Analysis of diatom communities constitutes a

\footnotetext{
* Corresponding author: valentina.dellabella@iss.it
}

valuable tool for general water quality monitoring and for the evaluation of more specific phenomena such as eutrophication and acidification (Prygel \& Coste 1995, Danilov \& Ekelund 2000, Kauppila et al. 2002, Kitner \& Poulíćková 2003). Diatoms are easy to sample in shallow waters and their use has practical advantages (King et al. 2000). They respond quickly to changes in environmental conditions and to anthropogenic pressures, therefore are often also used in paleolimnological studies for ecological reconstructions and for defining reference conditions in lakes as required by WFD (Denys 2003, Bennion et al. 2004, Bradshaw et al. 2006).

Although diatoms are regularly used as indicators in rivers and lakes, less is known about the benthic diatom communities in wetland systems worldwide. To date, periphyton were investigated and recently used as indicators of ecological conditions in wetlands mainly in some regions, such as the USA (Pan \& Stevenson 1996, Pan et al. 2000, Gaiser et al. 2005, Wang et al. 2006, Zheng \& Stevenson 2006) and Australia (Gell et al. 2002). In Italy, studies on benthic Diatoms are still 
limited and mainly focused on the assessment of water quality of rivers (Dell'Uomo 1996, 2004, Ciutti et al. 2003, Battegazzore et al. 2004, Cappelletti et al. 2005). Therefore, an extension of the knowledge on distribution, composition and structure of benthic diatom communities in ponds and wetlands, recognised as ecologically and functionally important elements of the aquatic ecosystems (CEC 2005), is especially important considering the requirements of the WFD.

This study on benthic diatom communities of nine of the last remnant freshwater and brackish wetlands in Northern coast of Latium (central Italy) had for its main aim to provide a contribution to (i) the characterization of these communities in wetland systems in Italy and (ii) the knowledge on the potential use of benthic Diatoms as biological indicators of this type of water body. This work is part of a more comprehensive and multidisciplinary program of the Environment Department of Rome Province focused to establish a program of measures and conservation strategies for these remnant wetland areas. Specifically, our research focused on an analysis of the taxonomic composition and structure of diatom communities and their relationships to physico-chemical variables of waters. Furthermore, a first application of some European diatom-based indices on this type of water body was undertaken.

\section{Materials and methods}

\section{Study area}

We conducted our investigation on nine freshwater and brackish wetland areas located along the Tyrrhenian coast near Rome (Fig. 1). Four of these wetland areas were part of the mouths of small rivers, three were coastal ponds and wetlands, and one was a lowland freshwater wetland (Table 1). The selected sites represent some of the last remnant wetlands of the Northern coast of Latium, which, in general, has been impacted by human activities (e.g. urbanization and agricultural practices) for a long time. Their coastal systems, surrounded by an urban and agricultural landscape, are highly vulnerable to several anthropogenic influences, including nutrient enrichment. Most of the study sites are now inside the protected area of Litorale Romano Natural State Reserve, including the WWF Oasis of Macchiagrande, and the others are in the Regional Natural Reserve of Macchiatonda and the Natural Monument of Torre Flavia Marsh. Moreover, some of these areas are proposed under the Birds Directive (CEC 1979) and the Habitats Directive (CEC 1992) as part of the Natura 2000 network (IT6030019/20/23; Regione Lazio 2004).

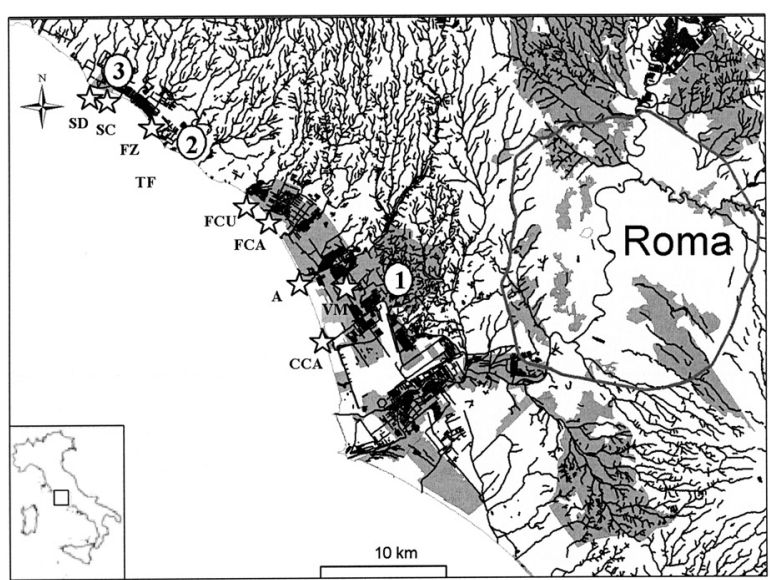

Fig. 1. Map of the sampling area. Stars indicate location of studied wetlands and numbers the protected areas: 1. Litorale Romano Natural State Reserve; 2. Natural Monument of Torre Flavia Marsh and 3. Regional Natural Reserve of Macchiatonda. For site codes see Table 1 .

\section{Sampling and laboratory methods}

We sampled Diatoms four times during 2005, in spring (March), early summer (May-June), late summer/early autumn (September) and early winter (December) in order to cover their whole growing season. Diatom sampling, sample treatment, and laboratory work were carried out according to the European recommendations (Kelly et al., 1998, EN 13946, 2003, EN 14407, 2004, King et al. 2006). Diatoms were sampled in all three habitats (epilithon, epiphyton, epipelon), where present within each site. In order to sample epilithic and epiphytic diatoms, the upper surface of 45 stones or aquatic vegetation (mainly emergent macrophytes) was scratched with a toothbrush. With a small pipe we sampled epipelic forms present on the surface of littoral sediment. Diatom samples from different substrates were then pooled obtaining one combined sample for each site. It was immediately examined or fixed and stored in $4 \%$ formaline. In order to identify the diatom frustules, the diatom valves were cleaned using hydrogen peroxyde to eliminate organic matter and with hydrochloric acid to dissolve calcium carbonate. Clean diatom frustules were mounted in a synthetic resin with high rifration index (Naphrax (C) and up to 400 valves were counted and identified to species or variety level in each sample using a light microscope with 1000x magnification. Measurements were made with the aid of image analysis software (Leica IM1000). Images of diatoms were digitized using a video camera (Leica DC 300) connected to a microscope (Optiphot-2) and to a computer. The main references for Diatom taxonomy were Krammer \& 
Table 1. Means and range (minimum and maximum values are reported in brackets) of physical and chemical features of studied wetlands $(\mathrm{N}=4)$. Wetland type is reported as RW = wetlands connected to river mouths; $\mathrm{CW}=$ coastal wetlands and $\mathrm{FW}=$ freshwater wetland.

\begin{tabular}{|c|c|c|c|c|c|c|c|c|}
\hline Site name & Code & Type & $\begin{array}{l}\mathrm{PO}_{4}^{3-} \\
\left(\mathrm{mg} \cdot l^{-1}\right)\end{array}$ & $\begin{array}{c}\mathrm{NO}_{3}^{-} \\
\left(\mathrm{mg} \cdot l^{-1}\right)\end{array}$ & $\mathrm{pH}$ & $\begin{array}{l}\text { Conductivity } \\
\left(\mathrm{mS} \cdot \mathrm{cm}^{-1}\right)\end{array}$ & $\begin{array}{c}\text { Salinity } \\
\% \text { o }\end{array}$ & $\begin{array}{c}\mathrm{Cl}^{-} \\
\left(\mathrm{mg} \cdot \mathrm{l}^{-1}\right)\end{array}$ \\
\hline $\begin{array}{l}\text { Collettore } \\
\text { Acque Alte }\end{array}$ & CAA & RW & $\begin{array}{c}3.09 \\
(0.13-10.66)\end{array}$ & $\begin{array}{c}9.02 \\
(2.34-19.51)\end{array}$ & $\begin{array}{c}7.86 \\
(7.49-8.53)\end{array}$ & $\begin{array}{c}4.87 \\
(0.38-9.3)\end{array}$ & $\begin{array}{c}2.7 \\
(0.0-5.2)\end{array}$ & $\begin{array}{c}351.55 \\
(149.58-469.03)\end{array}$ \\
\hline $\begin{array}{l}\text { Fosso } \\
\text { Zambra }\end{array}$ & $\mathrm{FZ}$ & RW & $\begin{array}{c}2.59 \\
(0.94-3.78)\end{array}$ & $\begin{array}{c}12.50 \\
(3.77-20.84)\end{array}$ & $\begin{array}{c}7.89 \\
(7.37-8.7)\end{array}$ & $\begin{array}{c}3.84 \\
(1.15-11.56)\end{array}$ & $\begin{array}{c}2.0 \\
(0.3-6.6)\end{array}$ & $\begin{array}{c}245.41 \\
(109.37-487.60)\end{array}$ \\
\hline $\begin{array}{l}\text { Fiume } \\
\text { Arrone }\end{array}$ & A & $\mathrm{RW}$ & $\begin{array}{c}1.88 \\
(1.38-2.89)\end{array}$ & $\begin{array}{c}19.30 \\
(17.41-21.28)\end{array}$ & $\begin{array}{c}7.91 \\
(7.75-8.25)\end{array}$ & $\begin{array}{c}0.86 \\
(0.68-0.99)\end{array}$ & $\begin{array}{c}0.2 \\
(0.1-0.3)\end{array}$ & $\begin{array}{c}82.07 \\
(66.16-101.99)\end{array}$ \\
\hline $\begin{array}{l}\text { Fosso delle } \\
\text { Cadute }\end{array}$ & FCA & RW & $\begin{array}{c}1.32 \\
(0.95-1.83)\end{array}$ & $\begin{array}{c}16.27 \\
(11.93-19.78)\end{array}$ & $\begin{array}{c}8.08 \\
(7.62-8.80)\end{array}$ & $\begin{array}{c}0.79 \\
(0.68-0.86)\end{array}$ & $\begin{array}{c}0.2 \\
(0.1-0.6)\end{array}$ & $\begin{array}{c}62.04 \\
(52.30-72.6)\end{array}$ \\
\hline $\begin{array}{l}\text { Fosso } \\
\text { Cupino }\end{array}$ & FCU & RW & $\begin{array}{c}1.25 \\
(0.40-1.76)\end{array}$ & $\begin{array}{c}13.46 \\
(7.05-19.46)\end{array}$ & $\begin{array}{c}8.23 \\
(7.65-9.55)\end{array}$ & $\begin{array}{c}0.93 \\
(0.66-1.55)\end{array}$ & $\begin{array}{c}0.2 \\
(0.1-0.6)\end{array}$ & $\begin{array}{c}101.50 \\
(52.66-230.75)\end{array}$ \\
\hline $\begin{array}{l}\text { Palude } \\
\text { Torre Flavia }\end{array}$ & $\mathrm{TF}$ & $\mathrm{CW}$ & $\begin{array}{c}1.02 \\
(0.66-1.39)\end{array}$ & $\begin{array}{c}1.55 \\
(0.71-3.81)\end{array}$ & $\begin{array}{c}7.46 \\
(7.10-7.80)\end{array}$ & $\begin{array}{c}2.21 \\
(1.02-3.35)\end{array}$ & $\begin{array}{c}1.0 \\
(0.3-1.7)\end{array}$ & $\begin{array}{c}304.53 \\
(86.46-422.05)\end{array}$ \\
\hline $\begin{array}{l}\text { Stagno } \\
\text { Costiero }\end{array}$ & $\mathrm{SC}$ & $\mathrm{CW}$ & $\begin{array}{c}0.37 \\
(0.24-0.45)\end{array}$ & $\begin{array}{c}0.76 \\
(0.70-0.82)\end{array}$ & $\begin{array}{c}8.46 \\
(7.32-10.37)\end{array}$ & $\begin{array}{c}16.30 \\
(5.18-30.50)\end{array}$ & $\begin{array}{c}9.7 \\
(2.8-18.9)\end{array}$ & $\begin{array}{c}488.51 \\
(455.08-529.2)\end{array}$ \\
\hline $\begin{array}{l}\text { Stagno } \\
\text { Didattico }\end{array}$ & SD & $\mathrm{CW}$ & $\begin{array}{c}0.23 \\
(0.17-0.26)\end{array}$ & $\begin{array}{c}0.84 \\
(0.78-0.90)\end{array}$ & $\begin{array}{c}8.38 \\
(7.64-9.64)\end{array}$ & $\begin{array}{c}1.65 \\
(0.93-2.61)\end{array}$ & $\begin{array}{c}0.6 \\
(0.2-1.2)\end{array}$ & $\begin{array}{c}270.63 \\
(108.70-406.3)\end{array}$ \\
\hline $\begin{array}{l}\text { Vasche di } \\
\text { Maccarese }\end{array}$ & VM & FW & $\begin{array}{c}0.33 \\
(0.07-0.60)\end{array}$ & $\begin{array}{c}0.85 \\
(0.67-1.04)\end{array}$ & $\begin{array}{c}7.98 \\
(7.40-8.4) \\
\end{array}$ & $\begin{array}{c}0.59 \\
(0.25-0.98) \\
\end{array}$ & $\begin{array}{c}0.1 \\
(0.0-0.3)\end{array}$ & $\begin{array}{c}71.69 \\
(0.27-118.65) \\
\end{array}$ \\
\hline
\end{tabular}

Lange-Bertalot (1986, 1988, 1991a, 1991b and 2000) and Prygiel \& Coste (2000). Also physical and chemical variables of the water were measured in the field at each sampling occasion: $\mathrm{pH}$, conductivity, salinity. Water samples were collected and analysed in the laboratory for nitrate $\left(\mathrm{NO}_{3}^{-}\right)$, phosphate $\left(\mathrm{PO}_{4}{ }^{3-}\right)$, and chloride $(\mathrm{Cl})$ contents, following standard methods reported in IRSA (1994), Wetzel and Likens (2000) and APHA (1998). The concentration of orthophosphate ions was determined photometrically after a reaction with molybdate ions in a solution acidified to form molybdophosphoric acid, then reduced by ascorbic acid to phosphomolybdenum blue. Nitrate ions content was determined photometrically after a reaction with sodium salicylate in strongly sulphuric solution to form a yellow dye. For the determination of chloride concentration, reaction of chloride ions with mercury (II) thiocyanate was used. The thiocyanate, released in the process, in turn forms with iron (III) ions red iron thiocyanate, the concentration of which is determined photometrically.

\section{Data analysis}

We employed Principal Component Analysis (PCA), based on six water characteristics of all 36 samples (9 sites $\mathrm{x} 4$ sampling occasions), to summarize variations among sites and to highlight environmental gradients. Before the analysis, all variables were standardized following $\mathrm{X}_{\mathrm{st}}=(\mathrm{X}-\bar{X}) / \mathrm{DS}$. The counts of each diatom taxon were expressed into relative abundance as a percentage of the total valves counted and identified. Four of 36 diatom samples and relative counts were excluded from the analysis because they were diluted; probably as a result of a flooding event and/or heavy rainfalls which altered the communities. In order to measure similarity among wetland diatom communities, we performed a 2-d Non metric Multidimensional Scaling (N-MDS) on the similarity matrix based on the Bray-Curtis similarity coefficient (Bray \& Curtis 1957, Clarke \& Warwik 1994) which was calculated on relative abundance of diatom taxa collected in the wetlands. In order to relate the Diatom species data to environmental data, a Canonical Correspondence Analysis (CCA) was applied. All six water chemistry variables were included in the analysis. We performed the ordination analyses at species level, and the removal of all species with less than two occurrences reduced the number of original data set of 225 species and varieties to 135 species. Before the analyses, the species relative abundance were $\arcsin \sqrt{ } \mathrm{p}$ transformed, in order to stabilize the variance (Sokal \& Rohlf, 1973) and environmental variables were standardized as for PCA above. We conducted our ordination analyses with STATISTICA (version 5), PRIMER 5 (version 5.2.0) and PCORD for Windows (version 3.09) softwares.

As a first application of existing diatom-based indices, we selected seven of the most widely employed indices in Europe for routine monitoring of rivers and that were representative of the three types of indices in which methods are generally classified: 
1) General quality indices: Diatom Biological Index (IBD; Lenoir \& Coste 1996, Prygiel \& Coste 2000); Eutrophication and pollution index (EPI-D; Dell'Uomo 2004); CEE index (Descy \& Coste 1991) and Generic Diatom Index (IDG; Coste \& Ayphassorho 1991), that responds to different pollution factors (nutrient, organic matter, chloride and oxygen contents in the water);

2) Trophic indices: Trophic Diatom Index (TDI; Kelly \& Whitton 1995) based on species sensitivity to nutrient contents of the waters. The calculation of correct scores for the TDI index is dependent on the percentage of tolerant diatom taxa to organic pollution in the sample (\%PT);

3) Saprobic indices: Taxa Pollution Tolerant (\%PT) and Pollution Sensitivity Index (IPS; CEMAGREF 1982), that responds only to organic pollution.

All indices were calculated and transformed to the scale from 0 to 20 to be comparable (with the exception of \%PT) using the OMNIDIA 7 software V 4.2 (Leiconte et al. 1993, 1999). Class boundaries and quality judgements from polluted (0) and clean waters (20) followed Dell'Uomo (2004).

Non-parametric Kruskal-Wallis ANOVA was adopted to compare water variables and taxal data among seasons and Spearman rank coefficient of correlation $\left(r_{s}\right)$ was adopted as initial test for relationships among indices and physico-chemical variables (Sokal and Rohlf 1973).

\section{Results}

\section{Physical and chemical characteristics of waters}

Environmental characteristics of the studied wetlands are shown in Table 1. The nine site data set had range for phosphate of $0.07-10.66 \mathrm{mg} \cdot \mathrm{l}^{-1}$ and nitrate of $0.67-21.28 \mathrm{mg} \cdot \mathrm{l}^{-1}$. These extremely high concentrations indicated generally enriched condition in the studied wetlands. The studied sites are distributed along a broad gradient of conductivity, salinity and chloride contents with ranges of $0.25-30.50 \mathrm{mS} \cdot \mathrm{cm}^{-1}$, $0.0-18.9 \%$ and $0.27-529.2 \mathrm{mg} \cdot \mathrm{l}^{-1}$, respectively. No significant seasonal patterns were observed in water variables with the exception of $\mathrm{pH}$ (Kruskal-Wallis ANOVA: $\mathrm{H}_{3,34}=10.78 ; \mathrm{p}<0.01$ ), which reached the highest values in most of the study sites in early summer. The first two components extracted in the PCA performed on physico-chemical variables accounted for $69.82 \%$ of variance in the original data (Fig. 2 and Table 2). PCA ordinated the study sites along the first axis according to their conductivity, salinity and chloride contents while the second axis arranged sites according to their phosphate concentrations. Fig. 2 illustrates how the most of the wetlands connected to river mouths are characterised by higher phosphate contents than ponds and wetlands, whereas coastal wetlands generally have more brackish waters.

Table 2. Factor loadings of physico-chemical variables used in the PCA analysis. The contributions $>10.70 \mathrm{l}$ are reported in bold.

\begin{tabular}{lcc}
\hline Variables & $\mathrm{PC} 1$ & $\mathrm{PC} \mathrm{2}$ \\
\hline $\mathrm{PO}_{4}{ }^{3-}$ & -0.13 & $\mathbf{- 0 . 7 6}$ \\
$\mathrm{NO}_{3}{ }^{-}$ & -0.56 & -0.31 \\
$\mathrm{pH}$ & 0.48 & -0.64 \\
Conductivity & $\mathbf{0 . 9 5}$ & -0.08 \\
Salinity & $\mathbf{0 . 9 5}$ & -0.10 \\
$\mathrm{Cl}^{-}$ & $\mathbf{0 . 8 2}$ & 0.25 \\
\hline Eigenvalues & 3.02 & 1.17 \\
Percentage of variance & 50.38 & 19.44 \\
explained & & \\
\hline
\end{tabular}

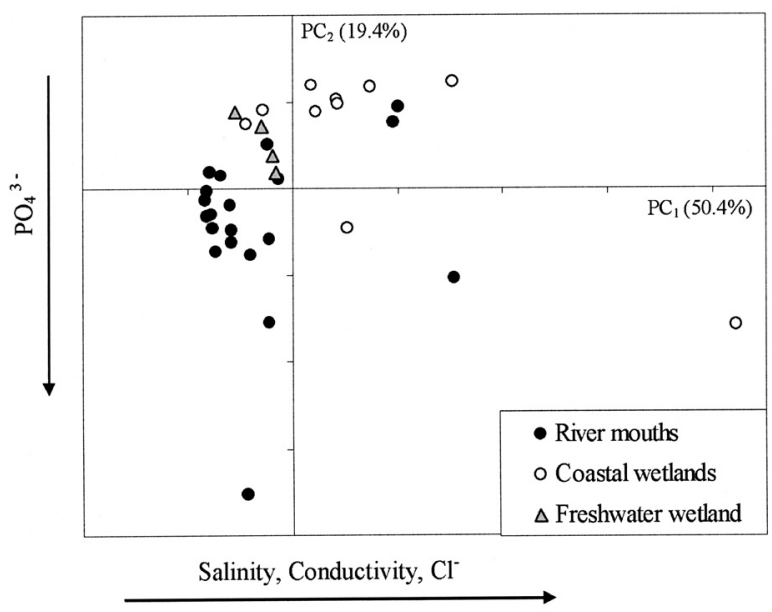

Fig. 2. Principal Component Analysis performed on physico-chemical variables of water samples (the percentage of variance explained by two first axes is reported in brackets). Arrows indicate variables with factor loadings $>10.701$.

\section{Diatom species richness and assemblages}

A total of 225 species and varieties were identified, belonging to 54 genera (Appendix 1). We found a mean of 36 species in each sample, with a minimum of 19 in early autumn and a maximum of 60 in winter (Fig. 3), collected in two wetlands connected to rivers (FCU and FCA). Although coastal and freshwater wetlands showed their highest taxonomic richness in early autumn (at the end of September), the seasonal trend in taxonomic richness of all studied sites was not 
significant. The genera containing the highest number of species (number given in parentheses) were Nitszchia A. H. Hassall (52) and Navicula Bory sensu lato (35), followed by Gomphonema C.G. Ehrenberg (16), Surirella P. J.F. Turpin (8), Fragilaria H.C. Lyngbye (7), Amphora C.G. Ehrenberg ex F.T. Kützing (6) and Planothidium Round \& Bukhtiyarova (6). Species present in more than $78 \%$ of all examined samples, frequent in all studied sites and in every sampling season, were Nitzschia constricta, N. palea, N. inconspicua, N. amphibia, Gomphonema parvulum and Navicula veneta. Very few species showed a significant seasonal pattern: Nitzschia dissipata, Surirella brebissonii were more frequent and abundant in studied wetlands in spring (Kruskal-Wallis ANOVA: $\mathrm{H}_{3,32}=15.0 ; \mathrm{p}<0.005$ and $\mathrm{H}_{3,32}=11.31 ; \mathrm{p}<0.01$, respectively), while Navicula recens in early autumn $\left(\mathrm{H}_{3,32}=8.81 ; \mathrm{p}<0.03\right)$, and Bacillaria paradoxa in winter $\left(\mathrm{H}_{3,32}=8.50 ; \mathrm{p}<0.03\right)$.

The N-MDS performed (two dimension, stress = 0.21 ) on relative abundances of 135 of the most frequent taxa collected during the study year in studied wetlands (32 samples), pointed to a clear separation among diatom communities of coastal wetlands, wetlands at river mouths and the freshwater wetland. The overall variation of diatom assemblages was greater among wetland type rather than among seasons (Fig. 4).

The Canonical Correspondence Analysis including six water variables, 135 species and 32 samples, permitted an analysis of relationships between diatom assemblages and physico-chemical variables and results are presented in Fig. 5. The first three axes of CCA explained $19.5 \%$ of cumulative variance. The first axis is positively correlated to conductivity, salinity and chloride concentration and negatively to phosphate and nitrate contents. Wetlands connected to river mouths, characterised by nutrient tolerant species such as Luticola goeppertiana, Mayamaea atomus, Eolimna subminuscula, Navicula pygmaea, Navicula pupula, Nitzschia capitellata, tended to be situated on the negative side of the axis, whereas coastal brackish wetlands with halophilous and also marine littoral species, that confer a certain distinctiveness to their flora, such as Nitzschia obtusa, Nitzschia elegantula, Amphora coffeaeformis, Achnanthes brevipes var. intermedia, Haslea spicula, Epithemia adnata var. porcellus, Anomoeoneis sphaerophora, Mastogloia spp. tended to be located on the positive side of the axis. The second axis is negatively correlated to nutrient and mineral contents and samples from the freshwater wetland are on the negative side of this axis and on the positive side of the first axis. Freshwater and less eutrophic species such as Achnanthidium minutissimum, Fragilaria capucina (many varieties), Cymbella microcephala, Achnanthidium biasolettianum e Gomphonema truncatum were found in these samples.

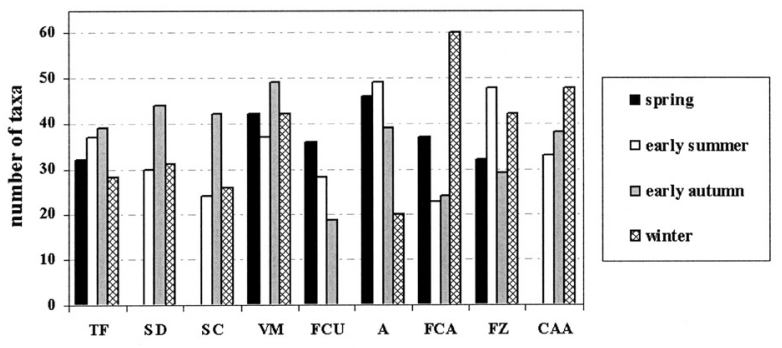

Fig. 3. Number of taxa found in studied wetlands for each sampling season.

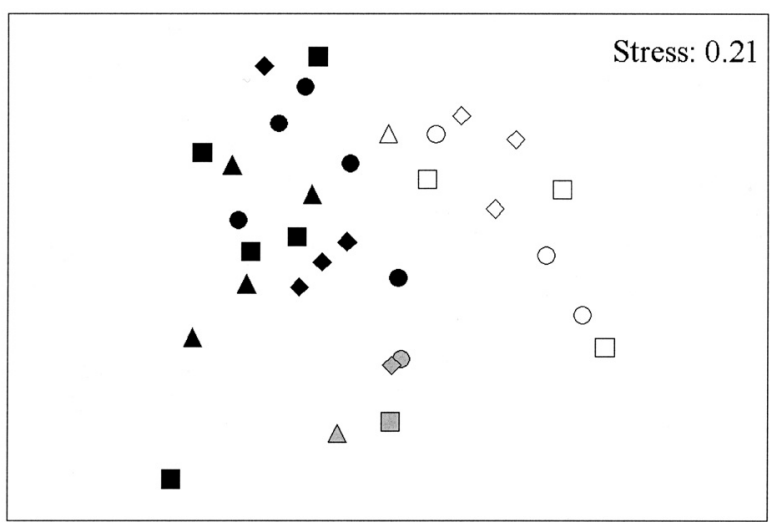

Fig. 4. N-MDS performed on diatom relative abundances found in all samples. Coastal wetlands are highlighted in white symbol, wetland at river mouth in black and the freshwater wetland in grey. The four sampling seasons were reported with different symbol : triangle $=$ spring; square $=$ summer; circle $=$ autumn; rhombus $=$ winter.

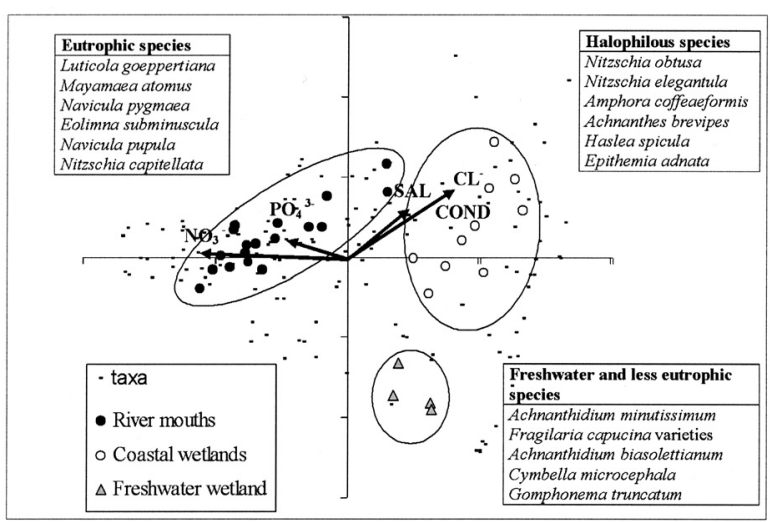

Fig. 5. Canonical Correspondence Analysis computed on the relative abundance of Diatoms in relation with the chemical and physical variables of waters . Cond $=$ Conductivity; Sal $=$ Salinity . 

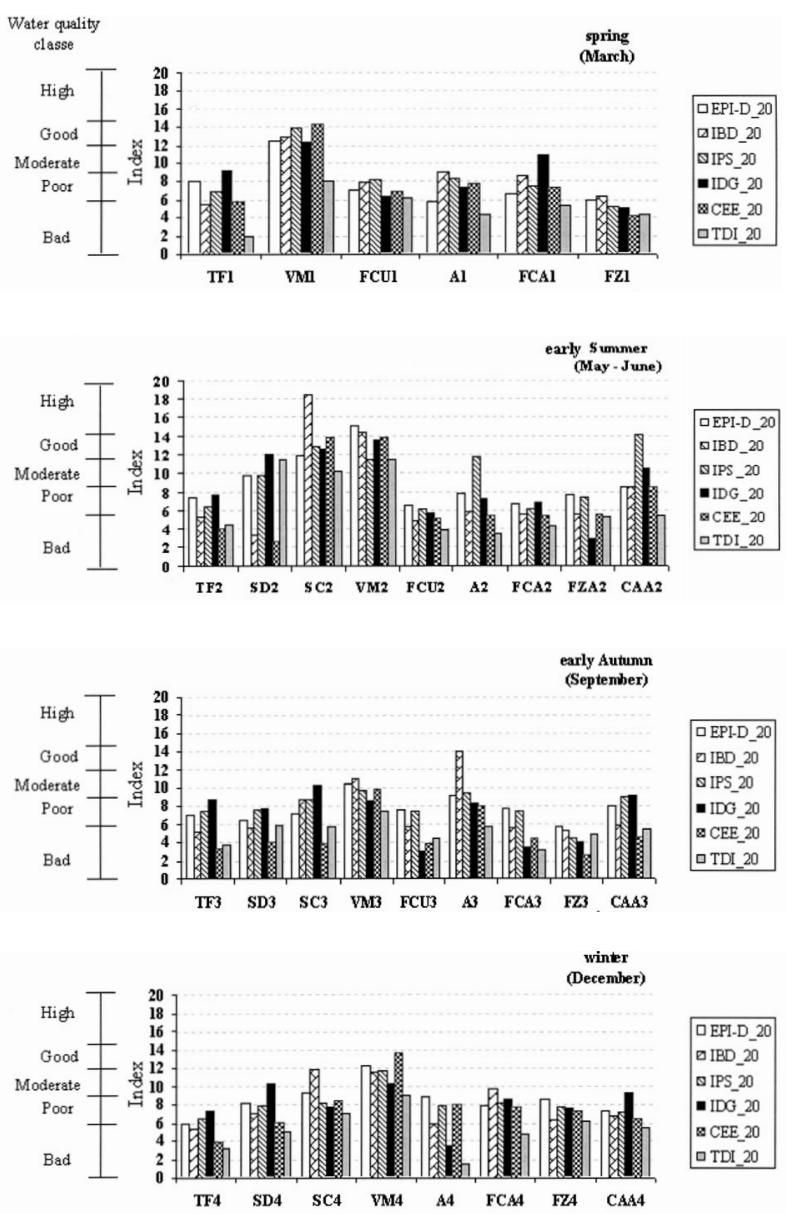

Fig. 6. Index values for each study site in each sampling period. Class boundaries followed Dell'Uomo (2004).

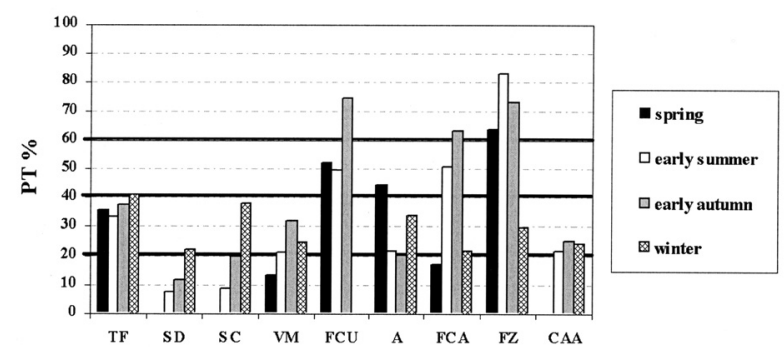

Fig. 7. Percentage of Pollution Tolerant Taxa (\%PT) in study site in each sampling period. Interpretation of proportion of count composed of taxa tolerant to organic pollution following Kelly and Whitton (1995): \% PT < 20 :organic pollution absent; $21<$ PT $\%<40$ : some evidence of presence of organic pollution; $41<\%$ PT $<60$ organic pollution likely contributes significally to eutrophication of site; \%PT> 61 : site is heavily contaminated with organic pollution.

\section{Performance of benthic Diatom indices}

Values of seven selected indices calculated for each study site in four sampling seasons are reported in Fig. 6 and 7. In general, following class boundaries suggested by Dell'Uomo (2004), the indices classified most of the studied water bodies as bad, poor and moderate status; few were classified into a good class by the indices at least for one sampling occasion. TDI index consistently classified all wetlands in a lower quality class in comparison to other indices in each sampling season. The percentages of Pollution Tolerant Taxa (\%PT) present in diatom counts in each site in four seasons are reported in Fig. 7, which illustrates that most of sites showed some evidence of organic pollution, at least in one sampling season. In three wetlands at river mouths (FCU, FCA and FZ), organic pollution is likely to have contributed to their eutrophication, and these sites was heavily contaminated with organic pollution especially at the beginning of summer and autumn. Spearman rank coefficient of correlation $\left(r_{s}\right)$, adopted as an initial test for relationships among indices and physico-chemical variables, showed that five of seven selected indices (TDI, \%PT, EPI-D, IPS and IDG) were significantly correlated to the nutrient contents of the water, in particular with phosphates (Table 3).

Tab. 3. Spearman correlation (rs) between indices and water variables. Significant correlations are indicated in bold $(* \mathrm{p}<0.05$; $* * \mathrm{p}<0.01 ; * * * \mathrm{p}<0.005 ; * * * \mathrm{p}<0.001)$.

\begin{tabular}{|c|c|c|c|c|c|c|}
\hline Index & $\mathrm{PO}_{4}{ }^{3-}$ & $\mathrm{NO}_{3}^{-}$ & $\mathrm{pH}$ & Cond & Sal & $\mathrm{Cl}^{-}$ \\
\hline TDI & $\mathbf{- 0 . 5 6} \mathbf{6}^{* * * *}$ & $-0.38^{*}$ & 0.11 & 0.04 & 0.05 & 0.21 \\
\hline IDG & $-0.65^{* * * *}$ & $-0.53 * * *$ & -0.02 & 0.04 & 0.04 & 0.18 \\
\hline$\% \mathrm{PT}$ & $0.57 * * * *$ & 0.27 & -005 & -0.03 & -0.03 & -0.11 \\
\hline EPI-D & $-0.47^{* *}$ & $-0.38^{*}$ & 0.11 & 0.04 & 0.05 & 0.08 \\
\hline IPS & $-0.56 * * * *$ & -0.23 & 0.08 & -0.04 & -0.04 & 0.04 \\
\hline CEE & -0.28 & -0.05 & 0.05 & -0.32 & -0.31 & -0.24 \\
\hline IBD & -0.32 & -0.06 & -0.05 & -0.18 & -0.17 & -0.10 \\
\hline
\end{tabular}

\section{Discussion}

Our results indicated that nutrient concentrations and chloride content of the water were the main variables which determine the composition and structure of benthic diatom communities in the studied coastal and river mouth wetlands of the Tyrrhenian coast near Rome. In our study area, as the ordination analysis (PCA) highlighted, wetlands directly connected to rivers had higher nutrient loading, especially of phosphates, than other brackish and freshwater ponds and wetlands. Urbanization and agriculture practices in the study area affect the basins of these small watercourses and continuously expose them to a high anthropogenic pressure (Mancini \& 
Arcà 2000). This suggests that, although some wetland areas at the mouth of these small rivers are already included in protected areas, their restoration requires, as a first step, upstream restoration actions on the water bodies that feed them, which are not always included in the protected areas, in order to limit the nutrient input.

The N-MDS and CCA plot indicated that certain species were closely associated with each wetland type and their distribution mainly depended on nutrient and salinity (in particular $\mathrm{Cl}$ ), e.g. pollution tolerant species in the wetlands connected to rivers, oligohaline species in the lowland freshwater wetland and halophilous species in the coastal ponds and wetlands. Marine littoral species were also collected in the last group of our studied wetlands and often found in brackish coastal pools and wetlands (Germain 1981, Alfinito et al. 1990, Denys 2003, Gaiser et al. 2005). In accordance with our findings, other studies on estuarine and coastal wetlands found that diatom species presence and abundance were related to a combined nutrient/salinity gradient. For examples, Underwood et al. (1998) and Zalat et al. (2005) found a similar spatial pattern of diatom assemblages based on nutrient and salinity gradient along a small estuarine ecosystem in United Kingdom and in three lakes in Egypt along the Mediteranean coast, respectively. An investigation on Murray River connected wetlands in Australia (Gell et al. 2002) also revealed salinity and nutrient control on the diatom taxa present, but demonstrated the dominance of salinity over nutrients on diatom assemblages once conductivity values exceed $\sim 2 \mathrm{mS} \cdot \mathrm{cm}^{-1}$, as it is the case of some of our studied sites in some sampling occasions. Salinity is also found to be the strongest variable influencing algal community composition in the Everglades (Florida, USA), on which it had an overriding control in comparison with the other studied variables, such as canopy height, organic content and peat depth (Gaiser et al. 2005). An overriding influence of salinity on diatom composition may be a problem in exploration of diatom-nutrient relationships in coastal ecosystems, and often it is not easy in field studies to separate the effects of nutrient contents from salinity.

As regards to the application of the selected indices developed for river quality evaluation, EPI-D, TDI, \%PT, IPS and IDG indices appear significantly correlated to the nutrient content of the study sites. TDI was the most severe index in the classification of study sites but, in general, they all classified the studied water bodies as bad, poor and moderate status, with the exception of two sites (the freshwater wetland and a coastal pond) that were classified into a good class by most of the indices, at least on one sampling occasion. It is surprising that the IDG index, although limited to a genus level identification, also seems to respond well to nutrient contents of these types of water bodies. It could be a valuable tool for wetland rapid bioassessments, to be used easily and quickly by non-specialised personnel. For this reason, other type of generic indices has already been developed for rivers in other continents (Wu 1999, Chessmann 1999). The advantage of a genus-level index may be realized in the time saved if a person or agency lacks expertise in Diatom identification but a lack of species-level identification precludes building databases on species distribution and their preferences or tolerance for physical and chemical conditions (Hill et al. 2001). Even if the selected indices seem correlated to nutrient concentration in our wetlands, careful consideration should be given to the application of these selected indices to wetland ecosystems at least for two reasons. First, they have been developed for water quality evaluation of flowing waters in different countries and are based on lists of species present in rivers at national level (Prygiel \& Coste 2000, Descy \& Coste 1991, Coste \& Ayphassorho 1991, Kelly \& Whitton 1995, CEMAGREF 1982, Dell'Uomo 2004). Therefore, not all species found in coastal wetlands could be included in their lists. For example, in our investigation an average of about $15 \%$ of species per sample are not included in the list of the Italian method EPI-D (Dell'Uomo 2004). Second, general quality indices, integrating the responses of the Diatom communities to different pollution factors (Coste \& Ayphassorho 1991, Prygiel \& Coste 2000) may not be the most suitable methods for the assessment of water quality in coastal systems where high mineral concentration, especially due to chloride content, is not a pollutant, as usually considered in the river, but rather has a natural origin due to the proximity of these wetlands to the seashore. This has to be taken into account in evaluation of water quality of this type of water body.

One of the major objectives of the WFD concerns the evaluation of the ecological status of water bodies. This does not imply application of any index to assess water quality, but rather a comparison of the community structure (such as species composition and abundance) to that of a water body of the same type in optimum reference conditions. This study provided a contribution to the knowledge on benthic diatom communities inhabit wetlands in Italy, and our preliminary data set illustrated the potential in the use of these benthic algae as bioindicators in this kind of water body. In order to meet the requirement of the WFD further detailed and intensive studies on wetland diatoms are needed to develop a reference base specific for these ecosystems, which are important for biodiversity conservation and play a strategic role in the management of the aquatic ecosystem (CEC 2005). 


\section{Acknowledgements}

The study was supported by a contract to V.D.B. from Rome Province. We wish to thank C. Battisti for coordinating the Rome Province program and M.E. Beltrami and S. Ciadamidaro for their valuable help in the field and laboratory work. We are also grateful to A. Dell'Uomo, M. Torrisi and L. Tudesque for their precious help in the taxonomic determination of some Diatom species. An early version of the manuscript was improved by the suggestions of two anonymous reviewers and the editing care of P. Nicolet.

\section{References}

Alfinito S., Iberite M. \& Fumanti B. 1990. - The algal microflora of the salt works of Tarquinia (Italy). Hydrobiologia, 203, 137-146.

APHA (American Public Health Association) 1998. - Standard methods for Examination of water and waste water. American Public Health Association, Washington DC. 1000 p.

Battegazzorre M., Gallo L., Lucadamo L. \& Morisi A. 2004. Quality of the main watercourses in the Pollino National Park (Appennine Mts., Italy) on the basis of Diatom benthic communities. Studi Trent. Sci. Nat., Acta Biol., 80, 89-93.

Bennion H., Fluin J. \& Simpson G.L. 2004. - Assessing eutrophication and reference conditions for Scottish freshwater lochs using subfossil diatoms. J. Appl. Ecol., 41, 124-138.

Blanco S., Ector L. \& Bécares E. 2004. - Epiphytic diatoms as water quality indicators in spanish shallow lakes. Vie Milieu, 54, 71-79.

Bradshaw E.G., A.B. Nielsen \& Anderson N.J. 2006. - Using diatoms to assess the impacts of prehistoric, pre-industrial and modern land-use on Danish lakes. Reg Environ Change, 6, 17-24.

Bray J.R. \& Curtis J.T. 1957. - An ordination of the upland forest communities of Southern Wisconsin. Ecol. Monogr., 27, 325-349.

Cappelletti C., Ciutti F., Crippa A., Mancini L., Beltrami M.E., Pierdominici E. \& Dell'Uomo A. 2005. - Diatomee come indicatori della qualità biologica dei corsi d'acqua. EPI-D ed altri metodi europei a confronto: il caso di studio del fiume Tevere. In: Atti del Seminario "Classificazione ecologica delle acque interne. Applicabilità della Direttiva 2000/60/CE. Trento 12-13 febbraio 2004. Biol. Amb., 19, 103-108.

CEC 1979. - Council of European Communities Directive 79/409/EEC on the conservation of wild birds. Official Journal of European Communities, C103.

CEC 1992. - Council of European Communities Directive 92/43/EEC on the conservation of natural habitats and of wild fauna and flora. Official Journal of European Communities, L206.

CEC 2000. - Council of European Communities Directive 2000/60/EEC of 23 October 2000 establishing a framework for community action in the field of water policy. Official Journal of European Communities, L327/1.

CEC. 2005. - Common Implementation Strategy for the Water Framework Directive (2000/60/EC). Guidance Document N12. Horizontal Guidance on the Role of Wetlands in the Water framework Directive, 17th December 2003. Official Journal of European Communities, Luxembourg.

CEMAGREF 1982. - Etude des méthodes biologiques d'appréciation quantitative de la qualité des eaux. Rapport Q.E. Lyon-A.F. Bassin Rhône-Méditerranée-Corse, Lyon, 218 p.

Chessman B., Growns I., Currey J. \& Plunkett-Cole N. 1999. Predicting diatom communities at the genus level for the rapid bioassessment of rivers. Freshwat. Biol. 41, 317-331.

Ciutti F., Cappelletti C. \& Corradini F. 2003. - Applicazione dell'indice EPI-D a un corso d'acqua delle Alpi (Torrente Fersina): osservazioni sulla metodica di determinazione delle abbondanze relative. Studi Trent. Sci. Nat., Acta Biol., 80, 95-100.
Clarke KR \& Warwick RM. 1994. - Change in Marine Communities: An Approach to Statistical Analysis and Interpretation. Natural Environment Research Council, Plymouth Marine Laboratory. Bourne Press limited, Bournemouth, 142 p.

Coste M. \& Ayphassorho H. 1991. - Etude de la qualité des eaux du bassin Artois-Picardie à l'aide des communautés de diatomées benthiques. Application des indices diatomiques au réseau. Cemagref Bordeaux. Agence de 1'Eau Artois-Picardie. Rapport Convention d'étude n. 90 X 3300 du 19 Juin 1990, 227 p.

Danilov R.A. \& Ekelund N.G.A. 2000. - The use of epiphyton and epilithon data as a base for calculating ecological indices in monitoring of eutrophication in lakes in central Sweden. Sci. Total Env. 248, 63-70.

Dell'Uomo A. 1996. - Assessment of water quality of an Appennine river as a pilot study for diatom-based monitoring of Italian watercourses. Pages 65-72. in Use of Algae for Monitoring Rivers II. Whitton B.A. \& Rott E. (eds.). Institut für Botanik, Universität Innsbruck.

Dell'Uomo A. 2004. - L'Indice Diatomico di Eutrofizzazione/ Polluzione (EPI-D) nel monitoraggio delle acque correnti. Linee Guida. APAT, CTN AIM, Roma, 101p.

DeNicola D.M. \& Eyto E. 2004. - Using epilithic algal communities to assess trophic status in irish lakes. J. Phycol., 40, 481-495.

Deny L. 2003. - Environmental changes in man-made coastal dune pools since 1850 as indicated by sedimentary and epiphytic diatom assemblages (Belgium). Aquatic Conserv: Mar. Freshw. Ecosyst. 13, 191-211.

Deny L. 2004. - Relation of abundance-weighted averages of diatom indicator values to measured environmental conditions in standing freshwaters. Ecological Indicators, 4, 225-275.

Descy J.P. \& Coste M. 1991. - A test of methods for assessing water quality based on diatoms. Verh. Internat. Verein. Limnol. 24 , 2112-2116.

EN 13946. 2003. - Water quality. Guidance Standard for the routine sampling and pre-treatment of benthic diatom samples from rivers, European Committee for Standardization, Brussels, $14 \mathrm{p}$.

EN 14407. 2004. - Water quality. Guidance Standard for the identification, enumeration and interpretation of benthic diatom samples from running waters. European Committee for Standardization, Brussels, 12 p.

Gaiser E. Wachnicka A., Ruiz P., Tobias F. \& Ross M. 2005. - Diatom indicators of ecosystem change in subtropical coastal wetlands. Pages 127-144 in Estuarine Indicators. Bortone, S. A. (ed). CRC Press Boca Raton, FL.

Gell P., Sluiter I. R. \& Fluin J. 2002. - Seasonal and interannual variations in diatom assemblages in Murray River connected wetlands in north-west Victoria, Australia. Mar. Freshw. Res., 53, 981-992.

Germain H. 1981. - Flore des Diatomées: eaux douces et saumâtres. Soc. Nouv. Ed. Boubée, Paris, 444p.

Hill B.H., Van Stevenson R., Pan Y., Herlihy A.T., Kaufmann P.R \& Johnson C.B. 2001 - Comparison of correlations between environmental characteristics and stream diatom assemblages characterized at genus and species levels. J. N. Am. Benthol. Soc. 20, 299-310.

Kauppila T., Moisio T. \& Salonen V.-P. 2002. - A diatom-based inference model for autumn epilimnetic total phosphorus concentration and its application to a presently eutrophic boreal lake. J. Paleolim. 27, 261-273.

Kelly M.G. \& Whitton B.A. 1995. - The Trophic Diatom Index: a new index for monitoring eutrophication in rivers. J Appl Phycol 7, 433-444. 
Kelly M.G., Cazaubon A., Coring E., Dell'Uomo A., Ector L., Goldsmith B., Guasch H., Hurlimann J., Jarlman A., Kawecka B., Kwandrans J., Laugaste R., Lindstrom E.A., Leitao M., Marvan P., Padisàk J., Pipp E., Prygiel J., Rott E., Sabater S., van Dam H. \& Vizinet J., 1998. - Recommendations for the routine sampling of diatoms for water quality assessments in Europe. J Appl Phycol $10,215-224$

King L., Barker P. \& Jones R.I. 2000. - Epilithic algal communities and their relationship to environmental variables in lakes of the English Lake District. Freshwat. Biol., 45, 425-442.

King L., Clarke G., Bennion H., Kelly M. \& Yallop M. 2006. Recommendations for sampling littoral diatoms in lakes for ecological status assessments. J. Appl. Phycol., 18, 15-25.

Kitner M. \& Pouličková A. 2003. - Littoral diatoms as indicators for the eutrophication of shallow lakes. Hydrobiologia, 506-509, 519-524.

Krammer K., Lange-Bertalot H., 1986, 1988, 1991a, 1991b, 2000. Bacillariophyceae. Teil: Naviculaceae; Bacillariaceae, Epithemiaceae, Surirellaceae; Centrales, Fragilariaceae, Eunotiaceae; Achnathaceae. Kritische Erganzungen zu Navicula und Gomphonema; and french translation of the keys. Süßwasserflora von Mitteleuropa, 2/1-5, Fischer, Stuttgart.

Leiconte C., Coste M., Prygiel J., 1993. - OMNIDIA: software for taxonomy, calculation of diatom indices and inventories management. Hydrobiologia 269/270, 509-513.

Leiconte C., Coste M., Prygiel J., Ector L., 1999. - Le logiciel OMNIDIA version 2, une puissante base de données pour les inventaries de diatomées et pour le calcul des indices diatomiquées européens. Cryptogamie, Algologie, 20, 132-134.

Lenoir A. \& Coste M. 1996. - Development of a practical diatom index of overall water quality applicable to the French national water Board network. Pages 29-43 in Use of algae for monitoring rivers II. Whitton B.A. \& Rott E. (eds). Proc. International Symposium, Innsbruck September 1995. Institut für Botanik, Universität Innsbruck, 196p.

IRSA 1994. - Metodi Analitici per le Acque. Istituto Poligrafico e Zecca dello Stato, CNR, Rome.

Mancini L. 2005. - Organization of biological monitoring in the European Union. Pages 171- 201 in Biological Monitoring of Rivers. Ziglio G., Siligardi M. \& Flaim G. (eds). John Wiley \& Sons, Ltd, London, 469p.

Mancini L. \& Arcà G. (eds) 2000 . - Carta della qualità biologica dei corsi d'acqua della Regione Lazio. Regione Lazio, Istituto Superiore di Sanità, Roma, 120 p.
Pan Y. \& Stevenson R.J. 1996. - Gradient analysis of diatom assemblages in western Kentucky wetlands. J. Phycol., 32, 222-232.

Pan Y., Stevenson R.J., Vaithiyanathan P., Slate J. \& Richardson C.J. 2000. - Changes in algal assemblages along observed and experimental phophorus gradients in a subtropical wetland, U.S.A. Freshwat. Biol. 44, 339-353.

Prygel J. \& Coste M. 1995. - Les diatomées et le diagnostic de la qualité des eaux courants continentales: les principales méthodes indicielles. Vie Milieu 45, 179-186.

Prygiel J., Coste M. \& Bukowska J. 1999. - Review of the major diatom-based techniques for the quality assessment of rivers. State of art in Europe. Pages 122-127 in Use of Algae for Monitoring Rivers, III. Prygiel J., Whitton B.A. \& Bukowska J. (eds.). Proc. International Symposium, Douai, France 29 September-1 October 1997. Agence de l'Eau Artois-Picardie, 271 p.

Prygiel J. \& Coste M. 2000. Guide metodologique pour la mise en oeuvre de l'Indice Biologique Diatomées - NFT 90-354.

Regione Lazio 2004. La Rete Natura 2000 nel Lazio. Caratterizzazione dei Siti di Importanza Comunitaria e delle Zone di Protezione per l'Attuazione della Sottomisura I.1.2, 2nd edn. Assessorato Ambiente, Dipartimento Territorio, Direzione Regionale Ambiente e Protezione Civile: Roma.

Sokal R.R. \& Rohlf G. 1973. - Introduction to biostatistics. Freeman \& Co., $368 \mathrm{p}$.

Underwood G.J.C., Philips J. \& Saunders K. 1998. - Distribution of estuarine benthic diatom species along salinity and nutrient gradients. Eur. J. Phycol. 33, 173-183.

Wang Y-K., Stevenson R.J. Sweet P.R. \& DiFranco J. 2006. Developing and testing diatom indicators for wetlands in the Casco Bay watershed, Maine, USA. Hydrobiologia, 561, 191-206.

Wetzel R.G. \& Likens G.E. 2000. - Limnological Analyses, 3rd edn. Springer-Verlag, New York.

Wu J-T . 1999. - A generic index of diatom assemblages as bioindicator of pollution in the Keelung River of Taiwan. Hydrobiologia, 397: 79-87.

Zalat A. \& Vildary S.S. 2005. - Distribution of diatom assemblages and their relationship to environmental variables in the surface sediments of three northern Egyptian lakes. J. Paleolim., 34,159-174.

Zheng L. \& Stevenson R.J. 2006. - Algal assemblages in multiple habitats of restored and extant wetlands. Hydrobiologia, 561, 221-238. 
Appendix 1. List of diatom species and varieties found in the studied wetlands.

Achnanthes brevipes var. intermedia (Agardh) Kützing

Achnanthidium alteragracillima (Lange-Bertalot)Round \& Bukhtiyarova Achnanthidium minutissimum (Kützing) Czarnecki

Achnanthidium saprophila (Kobayasi et Mayama) Round \& Bukhtiyarova Achnantidium biasolettianum (Grunow in Cl.\& Grun.) Round \& Bukhtiyarova Amphora veneta Kützing

Amphora coffeaeformis (Agardh) Kutzing var. coffeaeformis

Amphora inariensis Krammer

Amphora libyca Ehr.

Amphora montana Krasske

Amphora pediculus (Kützing) Grunow

Anomoeoneis sphaerophora (Ehr.) Pfitzer

Anomoeoneis sphaerophora (Ehr.) Pfitzer var. sculpta (Ehr.) O.Muller

Bacillaria paxillifera (O.F. Müller) Hendey var. paxillifer

Caloneis amphisbaena (Bory) Cleve

Caloneis molaris (Grunow) Krammer

Cocconeis pediculus Ehrenberg

Cocconeis placentula Ehrenberg var. placentula

Cocconeis placentula Ehrenberg var. euglypta (Ehr.) Grunow

Cocconeis placentula Ehrenberg var. lineata (Ehr.) Van Heurck

Craticula accomoda (Hustedt) Mann

Craticula ambigua (Ehrenberg) Mann

Craticula cuspidata (Kutzing) Mann

Craticula halophila (Grunow ex Van Heurck) Mann

Cyclotella atomus Hustedt

Cyclotella meneghiniana Kützing

Cyclotella ocellata Pantocsek

Cymatopleura elliptica (Brebisson)W.Smith var. elliptica

Cymatopleura solea (Brebisson) W.Smith var. apiculata (W.Smith) Ralfs

Cymatopleura solea (Brebisson) W.Smith var. solea

Cymbella affinis Kutzing var. affinis

Cymbella pusilla Grunow in A.Schmidt \& al.

Denticula subtilis Hustedt

Diadesmis confervacea Kützing

Diadesmis contenta (Grunow ex V. Heurck) Mann

Diatoma vulgaris Bory 1824

Diploneis elliptica (Kutzing) Cleve

Discostella stelligera (Cleve et Grun.) Houk \& Klee

Encyonema minutum (Hilse in Rabh.) D.G. Mann

Encyonema neogracile Krammer

Encyonema silesiacum (Bleisch in Rabh.) D.G. Mann

Encyonopsis cesatii (Rabenhorst) Krammer

Encyonopsis microcephala (Grunow) Krammer

Eolimna minima (Grunow) Lange-Bertalot

Eolimna subminuscula (Manguin) Moser Lange-Bertalot \& Metzeltin

Epithemia adnata (Kutzing) Brebisson var. porcellus (Kutzing) Patrick

Epithemia argus (Ehrenberg) Kutzing var. argus

Epithemia sorex Kutzing

Eucocconeis laevis (Oestrup) Lange-Bertalot

Fallacia aequora (Hustedt) D.G. Mann

Fallacia pygmaea (Kützing) Stickle \& Mann ssp. pygmaea Lange-Bertalot

Fallacia subhamulata (Grunow in V. Heurck) D.G. Mann

Fallacia tenera (Hustedt) Mann in Round

Fistulifera pelliculosa (Brebisson) Lange-Bertalot

Fistulifera saprophila (Lange-Bertalot \& Bonik) Lange-Bertalot

Fragilaria capucina Desm. var. rumpens (Kütz.) Lange-Bert. ex Bukht.

Fragilaria capucina Desmazieres var. capitellata (Grunow) Lange-Bertalot

Fragilaria capucina Desmazieres var. capucina

Fragilaria capucina Desmazieres var. distans (Grunow) Lange-Bertalot

Fragilaria capucina Desmazieres var. vaucheriae (Kutzing) Lange-Bertalot

Fragilaria tabulata var. truncata Lange-Bertalot

Fragilaria ulna (Nitzsch.) Ehr. var. spathulifera (Grunow) Lange-Bertalot

Frustulia vulgaris (Thwaites) De Toni
Geissleria acceptata (Hust.) Lange-Bertalot \& Metzeltin

Geissleria decussis (Ostrup) Lange-Bertalot \& Metzeltin

Gomphonema acuminatum Ehrenberg

Gomphonema affine Kützing

Gomphonema angustatum (Kützing) Rabenhorst

Gomphonema angustum Agardh

Gomphonema bohemicum sensu Hustedt

Gomphonema calcifugum Lange-Bertalot \& Reichardt

Gomphonema clavatum Ehrenberg

Gomphonema exilissimum (Grun.) Lange-Bertalot \& Reichardt

Gomphonema gracile Ehrenberg

Gomphonema micropus Kutzing var. micropus

Gomphonema minutum (Ag.)Agardh f. minutum

Gomphonema olivaceum (Hornemann) Brébisson var. olivaceum

Gomphonema parvulum Kützing

Gomphonema parvulum var. parvulum f. saprophilum Lange-Bert.\&Reichardt

Gomphonema tergestinum Fricke

Gomphonema truncatum Ehrenberg

Gyrosigma acuminatum (Kützing)Rabenhorst

Gyrosigma attenuatum (Kützing) Rabenhorst

Gyrosigma nodiferum (Grunow) Reimer

Gyrosigma peisonis (Grunow) Hustedt

Gyrosigma scalproides (Rabenhorst) Cleve

Hantzschia amphioxys (Ehr.) Grunow in Cleve et Grunow 1880

Hanztschia spectabilis (Ehrenberg) Hustedt

Haslea spicula (Hickie) Lange-Bertalot

Hippodonta hungarica (Grunow) Lange-Bertalot Metzeltin \& Witkowski

Lemnicola hungarica (Grunow) Round \& Basson

Luticola goeppertiana (Bleisch in Rabenhorst) D.G. Mann

Luticola mutica (Kützing) D.G. Mann

Luticola nivalis (Ehrenberg) D.G. Mann

Luticola ventricosa (Kützing) D.G. Mann

Mastogloia elliptica (C.A. Agardh) Cleve

Mastogloia pumila (Grunow) Cleve

Mayamaea atomus (Kutzing) Lange-Bertalot

Mayamaea atomus var. permitis (Hustedt) Lange-Bertalot

Melosira varians Agardh

Navicula (dicta) seminulum (Grunow) Lange Bertalot

Navicula agnita Hustedt

Navicula associata Lange-Bertalot

Navicula capitatoradiata Germain

Navicula cari Ehrenberg

Navicula cincta (Ehrenberg) Ralfs

Navicula cincta (Ehrenberg) Ralfs f. minuta

Navicula cryptocephala Kützing

Navicula cryptotenella Lange-Bertalot

Navicula digitoradiata (Gregory) Ralfs

Navicula duerrenbergiana Hustedt in Schmidt et al.

Navicula erifuga Lange-Bertalot

Navicula exilis Kutzing

Navicula gregaria Donkin

Navicula lanceolata (Agardh) Ehrenberg

Navicula libonensis Schoeman

Navicula menisculus Schumann var. menisculus

Navicula peregrina

Navicula phyllepta Kützing

Navicula radiosa Kutzing

Navicula radiosafallax Lange-Bertalot

Navicula recens (Lange-Bertalot) Lange-Bertalot

Navicula reichardtiana Lange-Bertalot

Navicula salinarum Grunow in Cleve et Grunow var. salinarum

Navicula salinicola Hustedt

Navicula schroeteri Meister var. schroeteri 
Appendix 1. continued.

Navicula schroeteri Meister var. symmetrica (Patrick) Lange-Bertalot Navicula tenelloides Hustedt

Navicula tripunctata (O.F.Muller) Bory

Navicula trivialis Lange-Bertalot var. trivialis

Navicula veneta Kützing

Navicula viridula var. germainii (Wallace) Lange-Bertalot

Navicula viridula (Kutz.) Ehr. var. rostellata (Kutz.) Cleve

Navicula viridula (Kutzing) Ehrenberg

Navicula wiesneri Lange-Bertalot

Nitzschia acicularis (Kutzing) W.M.Smith

Nitzschia amphibia Grunow

Nitzschia angustatula Lange-Bertalot

Nitzschia aurariae Cholnoky

Nitzschia brevissima Grunow

Nitzschia capitellata Hustedt

Nitzschia clausii Hantzsch

Nitzschia communis Rabenhorst

Nitzschia compressa (J.W.Bailey) Boyer

Nitzschia constricta (Kützing) Ralfs

Nitzschia dissipata (Kützing) Grunow

Nitzschia dissipata (Kutzing) Grunow var. media (Hantzsch.) Grunow

Nitzschia dubia W.M.Smith

Nitzschia elegantula Grunow

Nitzschia filiformis (W.M.Smith) Van Heurck var. filiformis

Nitzschia filiformis var. conferta (Richter) Lange-Bertalot

Nitzschia fonticola Grunow in Cleve et Muller

Nitzschia frustulum (Kützing) Grunow

Nitzschia frustulum (Kützing) Grunow var. bulnheimiana (Rabh.) Grunow

Nitzschia granulata Grunow in Cleve et Muller

Nitzschia hungarica Grunow

Nitzschia inconspicua Grunow

Nitzschia intermedia Hantzsch ex Cleve \& Grunow

Nitzschia levidensis (W.Smith) Grunow in Van Heurck

Nitzschia levidensis (W.Smith) Grunow var. salinarum Grunow in Van Heurck

Nitzschia levidensis (W.Smith) Grunow var. victoriae (Grunow) Cholnoky

Nitzschia liebetruthii Rabenhorst var. liebetruthii

Nitzschia linearis (Agardh) W.M.Smith var. linearis

Nitzschia linearis (Agardh) W.M.Smith var. subtilis (Grunow) Hustedt

Nitzschia linearis (Agardh) W.M.Smith var. tenuis (W.Smith) Grunow

Nitzschia lorenziana Grunow in Cleve et Muller

Nitzschia microcephala Grunow

Nitzschia modesta Hustedt

Nitzschia nana Grunow in Van Heurck

Nitzschia obtusa W.M.Smith var. obtusa

Nitzschia ovalis Arnott ex Grunow in Cl. \& Grun.

Nitzschia palea (Kützing) W. Smith

Nitzschia palea (Kützing) W.Smith var. debilis (Kutzing) Grunow in Cl. \& Grun

Nitzschia palea (Kützing) W.Smith var. tenuirostris Grunow in V. Heurck

Nitzschia parvuloides Cholnoky
Nitzschia prolongata Hustedt var. hoehnkii (Hustedt) Lange-Bertalot

Nitzschia pusilla (Kützing) Grunow

Nitzschia recta Hantzsch in Rabenhorst

Nitzschia rosenstockii Lange-Bertalot

Nitzschia semirobusta Lange-Bertalot

Nitzschia sigma (Kützing)W.M.Smith

Nitzschia sigmoidea (Nitzsch)W. Smith

Nitzschia sociabilis Hustedt

Nitzschia subacicularis Hustedt in A.Schmidt et al.

Nitzschia supralitorea Lange-Bertalot

Nitzschia umbonata (Ehrenberg) Lange-Bertalot

Nitzschia vermicularis (Kützing) Hantzsch

Pinnularia brebissonii (Kutz.) Rabenhorst var. brebissonii

Pinnularia microstauron (Ehr.) Cleve var. microstauron

Placoneis clementis (Grun.) Cox

Planothidium delicatulum (Kützing) Round \& Bukhtiyarova

Planothidium ellipticum $(\mathrm{Cl}$.)Round \& Bukhtiyarova

Planothidium frequentissimum (Lange-Bertalot)Round \& Bukhtiyarova

Planothidium lanceolatum (Brebisson ex Kützing) Lange-Bertalot

Planothidium rostratum (Oestrup) Lange-Bertalot

Pleurosigma elongatum $\mathrm{W}$. Smith

Pseudostaurosira brevistriata (Grun.in Van Heurck) Williams \& Round

Rhoicosphenia abbreviata (Agardh) Lange-Bertalot

Rhopalodia constricta (W. Smith) Krammer

Sellaphora mutata (Krasske) Lange-Bertalot

Sellaphora pupula (Kützing) Mereschkowksy

Seminavis strigosa (Hustedt) Danieledis \& Economou-Amilli

Stauroneis obtusa Lagerstedt

Stauroneis smithii Grunow

Staurosira construens Ehrenberg

Staurosira elliptica (Schumann) Williams \& Round

Staurosira venter (Ehr.) Cleve \& Moeller

Stephanodiscus hantzschii Grunow in Cl. \& Grun. 1880

Surirella angusta Kützing

Surirella brebissonii Krammer \& Lange-Bertalot

Surirella brebissonii var. kuetzingii Krammer et Lange-Bertalot

Surirella linearis W. M. Smith

Surirella linearis W. M. Smith var. constricta Grunow

Surirella minuta Brebisson

Surirella ovalis Brebisson

Surirella suecica Grunow

Synedra fasciculata Kützing

Synedra gaillonii (Bory) Ehrenberg

Thalassiosira weissflogii (Grunow) Fryxell \& Hasle

Tryblionella calida (Grunow in Cl. \& Grun.) D.G. Mann

Tryblionella littoralis (Grunow in Cl. \& Grun.) D.G. Mann

Ulnaria biceps (Kützing) Compère

Ulnaria ulna (Nitzsch.) Compère 